\title{
Origin and nature of humic substances in the waters of the Amazon River Basin
}

\author{
Jerry A. Leenheer $\left({ }^{*}\right)$
}

\begin{abstract}
Humic substances dissolved in "black water, white water, and clear water" rivers of the Amazon River basin were compared were humic substances found in podzolic (spodic) and latosolic (oxic) soils of the Amaon region. Humic-type organic solutes in black water originated from organic matter decomposition and ground water drainage from podzolic soils; clear water drains from latcsols because colored humic solutes are adsorbed on clay minerals contained in latosols. Comparisons of organic solute distributions in tropical surface waters versus temperate surface waters by dissolved organic carbon fractionation analysis show that the only significant difference was a lower hydrophilic neutral content of tropical surface waters. This finding is indicative of more rapid decay processes in tropical waters. Black-water rivers of the Amazon contained ondy one-third to one-half the organic solute content contained in black-water rivers of the southeastern United States. About 50 percent of the organic carbon in black waters of the Amazon consisted of colorless ron-humic organic solutes. Humic solutes contained in Amazon black water differed from humic solutes found in the Suwannee River in the southeastern United States by having a higher $E_{4} / E_{6}$ ratio in the visible absorbance spectrum which resulted in water of a more reddish coloration. Both the high $E_{4} / E_{6}$ ratio and low-angle $x$-ray scattering data suggest relatively small molecular dimensions for humic solutes in Amazon black water. Organic elemental analyses and infrared analysis of humic substances in Amazon waters and soils were typical for humic substances except for the low content of nitrogen for humic solutes in black water.
\end{abstract}

\section{INTRODUCTION}

Surface waters of the Amazon River Basin have long been classified on the basis of their appearance into black water, white water, and clear water (Wallace, 1899; Sioli, 1950). Waterquality studies of these waters have focused primarily on the nature of inorganic solutes and suspended sediment, rather than organic constituents, which control the water chemistry, especially in black waters. Organic con- stituents of these waters has been assessed by dissolved organic carbon (Williams, 1968), and concentrations of humic materials were determined by colorimetry (Santos \& Santos, 1970); however, the amount of data collected is small, and little work has been performec on the origin and nature of organic constituents. It is known that ground-water drainage from podzol soils is the primary source of black waters (Klinge, 1966), and that organic materials responsible for coloration of these waters have chemical and physical properties similar to humic substances in soil (Ziech. mann, 1976).

Most fundamental research about the ori. gin and chemical characteristics of humic substances in soils (Schnitzer \& Kahn, 1978) and water (Christman \& Ghassemi, 1966) has been performed on soils and waters of temperate climatic zones. The objectives of this report are to present findings on the origin ana nature of natural organic solutes in the tropica! waters of Amazonia, and to compare these findings with the body of knowledge on natural organic solutes in temperate waters, to better obtain an understanding of organic-geochemical processes in surface waters of both temperate and tropical environments.

\section{SAMPLING AND LABORATORY PROCEDURES}

Water and soil samples were collected near Manaus, Amazonas, from February 15 to April 30, 1978. Samples were collected from two forest reserves (Reserve Ducke and Reserve $60 \mathrm{~km}$.) of the Instituto Nacional de Pesquisas da Amazonia (INPA), and from blackwater rivers during a 10-day river trip on the Rio Negro from Manaus to the mouth of the Rio Branco. Laboratory studies were performed

(*) - U.S. Geological Survey Water Resources Division. Denver, Colorado. 
at the INPA research facility in Manaus, and at the National Water Quality Laboratory of the U.S. Geological Survey in Denver, Colorado.

\section{SAMPLING PROCEDURES}

Soil samples were collected to a depth of one meter with a soil auger. Samples at greater depth were collected in road cuts along the highway from Manaus to Boa Vista. Soil samples were stored in plastic bags and were processed at the INPA laboratory within one week after collection.

All water samples were dip samples collected at the water surface. water samples were filtered within one day after collection through a $0.45 \mu \mathrm{m}$ porosity, silver-membrane filter. The pressure-filtration apparatus is described in a report by Malcolm \& Leenheer (1973). The silver filter was used because it does not adsorb organic solutes and preserves the sample by the release of silver into solution. Water was stored in 1-liter glass bottles with Teflon-lined screw caps; these bottles were shipped to the United States in fittea Styrofoam packers.

\section{LABORATORY PROCEDURES PERFORMED AT INPA}

Humic substances were extracted under nitrogen from the moist soils using 10 parts $0.05 \mathrm{~N} \mathrm{NaOH}$ to one part soil for a one-day period. The weaker $0.05 \mathrm{~N} \mathrm{NaOH}$ solution was used to extract humic substances rather than the standard $0.1 \mathrm{~N} \mathrm{NaOH}$ solution, because $0.05 \mathrm{~N} \mathrm{NaOH}$ was observed to be an efficient extraction agent for these particular soils; only one-half the amount of cation-exchange resin was required to remove it from solution, and the lower $\mathrm{pH}$ (12.5 vs 13 ) provided milder extraction conditions.

The bulk of the soil was separated from solution by centrifugation, and fine sediment was removed from $50 \mathrm{ml}$ of decant solution by pressure filtration through a $0.45 \mu \mathrm{m}$ silvermembrane filter. Sodium hydroxide was removed from the filtrate by passage through a 20-ml column packed with a hydrogen-saturated, strong-acid cation-exchange resin (Bio-
Rad AG-MP-50). The eluate was collected in a $100-\mathrm{ml}$ glass bottle with a Teflon-lined screwcap.

Humic substances were extracted from filtered water samples by acidifying the water to $\mathrm{pH} 2$ with $\mathrm{HCl}$, and pumping the water through a column of cleaned Amberlite XAD-8 resin. A $100-\mathrm{mL}$ resin column was used; water volume was $5 \mathrm{~L}$; and the flow rate was $8 \mathrm{~mL} /$ min. Humic substances adsorbed on the XAD-8 resin were eluted by $200 \mathrm{~mL}$ of $0.05 \mathrm{~N} \mathrm{NaOH}$, which was immediately removed by passing the eluate through a $20-\mathrm{mL}$ column of hydrogensaturated cation-exchange resin. Humic so lutes in a 20-liter "black water" sample ob tained at a spring draining a podzol soil were extracted and concentrated to $800-\mathrm{mL}$ by this technique.

Visible-light absorbance spectra were determined by incremental readings on a singiebeam spectrophotometer. The ratio of humic to fulvic acid in an extract was determined by the difference in solution measurement of absorbance at $400 \mathrm{~nm}$ before and after humic acid precipitation at $\mathrm{pH} 1$. Precipitated humic acid was removed from solution by centrifugation. This method of humic and fulvic acid measurement gives only approximate values because molar absorptivity values for humis and fulvic acids differ slightly.

The percentage contribution of humic anc fulvic acids to the total acidity of a black-water sample was determined in the following manner A sample $(500 \mathrm{~mL}, \mathrm{pH} 3.85)$ was titrated with $0.5 \mathrm{ml}$ increments of $0.05 \mathrm{~N} \mathrm{NaOH}$ to $\mathrm{pH} 10$. The approximate inflextion point of the titration was $\mathrm{pH} 8.5$. Humic and fulvic acids in $500 \mathrm{~mL}$ of this sample were isolated arid concentrated using XAD-8 resin into 100 $\mathrm{mL}$ of water in the manner described previously; this sample was titrated with $0.05 \mathrm{~N} \mathrm{NaOH}$ to $\mathrm{pH}$ 8.5. A blank run which passed distilled water through the resin adsorbents had to be performed to.correct for the small amount of $\mathrm{HCl}$ added during the procedure. The quotient of the corrected extract titration divided by the whole-water titration was a measure of the percentage of humic-and fulvic-acid acidity in black water. 
LABORATORY PROCEDURES PERFORMED AT U.S. GEOLOGICAL SURVEY

Soil and water extracts were freeze-dried according to the procedure described by Malcolm (1968). Elemental analyses (C, H, O, $\mathrm{N}$., and ash) were performed by Huffman Laboratories, Wheat Ridge, Colorado. Intrared spectra were performed by incorporating humic substances into $\mathrm{KBr}$ micropellets, and measuring the spectra on a Model 580 Perkin Elmer Infrared Spectrophotometer.

Dissolved organic carbon (DOC) fractionation analysis was used to quantify organicsolute concentrations, and to characterize organic- solute compound classes in the various waters sampled. A description of the research and development of the method is given in a report by Leenheer \& Huffman (1976); the standard procedure, interpretation of data, and applications of the method are presented in a second report by Leenheer \& Huffman (1979). The analytical scheme for DOC fractionation is given in Figure 1. DOC

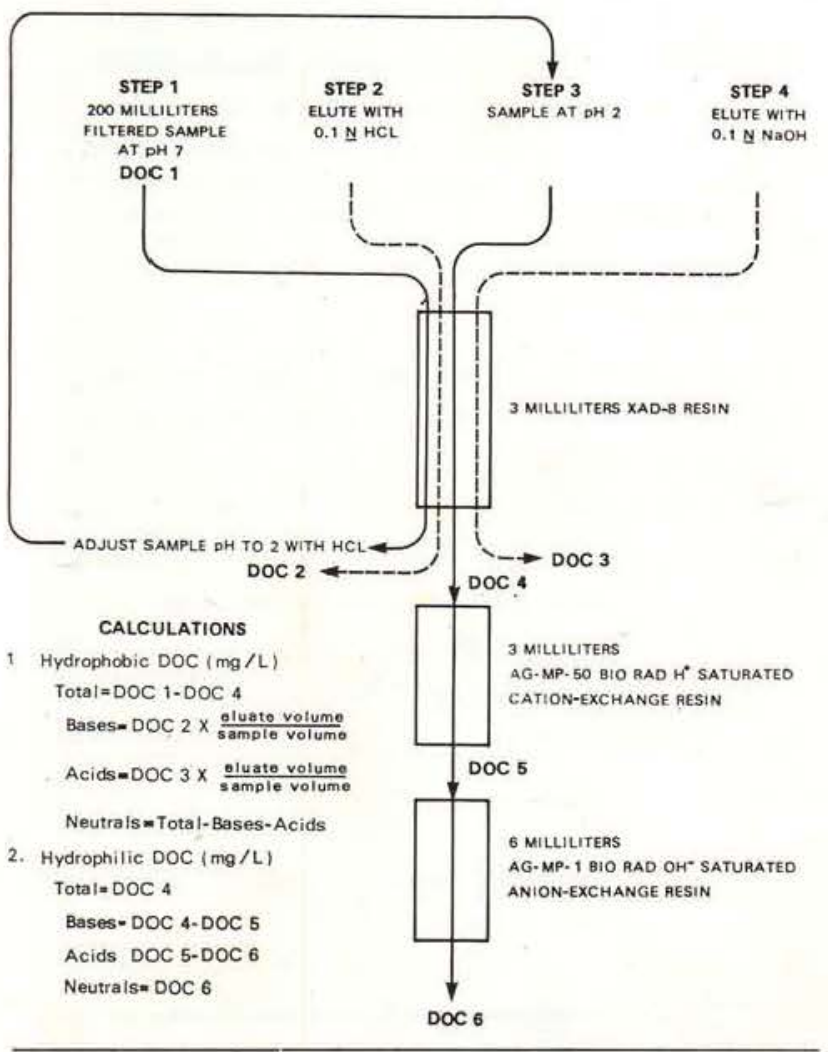

Fig. 1 - Dissolved organic carbon fractination analytical scheme. fractionation analyses were also performed by Huffman Laboratories.

Molecular sizes of humic solutes in water were estimated by measuring the radius of gyration of these solutes, as determined by low-angle X-ray scattering. Low-angle X-ray scattering measurements were performed by a Kratky low-angle scattering goniometer on one-percent solutions (weight/volume) of the freeze-dried humic preparations dissolved in distilled water, and a pH-7 phosphate buffer. The experimental procedure and data processing are presented in a report by Wershaw \& Pinckney (1973a).

\section{RESULTS AND DISCUSSION}

ORIGIN OF HUMIC SUBSTANCES IN BLACK WATER

Field observations substantiated the fact that lateral ground-water drainage from podzol (Spodosol) soils developed on alluvial sana deposits are the source of black water. However, not all podzol soils produce black water. The campina forest, that grows on the deep podzols whose albic horizon is several meters $(>3 \mathrm{~m})$ thick, produces only a small amount of organic matter that can degrade into humic substances. Consequently, much of the water that drains from sparsely-vegetated campina forests is clear water that contains small concentrations of humic material.

Black water is derived primarily from shallow podzols whose albic horizon is only a few meters $(<3 \mathrm{~m})$ thick. Beneath the albic horizon, a spodic horizon, rich in humic material, is often found above a clay lens, or above clayey parent material which underlies alluvial sands. Plant growth is enhanced when roots penetrate through the albic horizon into the spodic and underlying clay horizons due to the greater fertility of the deeper horizons. Greater input of plant litter leads to greater input of humic substances into ground water; these humic substances are relatively stable in ground water occurring in podzol sands, because of lack of nutrients, lack of light, lack of clay to remove humic materials through sorption, and a relatively anaerobic system which inhibits oxidation, compared to aerobic 
decay processes near soil surface. In the shallow podzols, humic materials are not sorbed by underlying clay because the spodic horizon rich in previously deposited humic substances has saturated active sorption sites on the clay, and also acts as a hydrologic barrier, thus preventing infiltration of black water into the underlying clay, where additional sorption of humic substances can occur. A thick, organic litter layer accumulates at the surface of shallow podzols; slow decay of this litter layer provides a continuous source of soluble humic substances, which are responsibie for coloration of black water.

Drainage (both surface and ground water) from latosolic soils is generally clear water, low in organic content. These soils do not have a thick, organic litter layer. The lack of this layer. The lack of this layer is indicative of more rapid decay processes than those which occur on shallow podzols. Presence of a brown A horizon $5-20 \mathrm{~cm}$ thick indicates sorption of soluble humic materials upon the yeliow and red clays. Therefore, because of more rapid decay and sorption, soluble humic substances do not occur in high concentrations in waters which drain latosols.

The soil organic-matter source for humic solutes in river waters of the Amazon is different from the swamp-water source of humic solutes in some coastal plain rivers of the southeastern United States. Beck et al. (1974) reported that decaying vegetation within these southeastern United States swamps produced waters with two to three times the organicsolute content as waters which drained the soils of this region. The greater amounts of rainfall in the Amazon region may reduce organic solute content of Amazon rivers by dilution.

VISIBLE ABSORBANCE SPECTRA OF BLACK WATER

Black waters of the Amazon are coiored reddish-brown; the red coloration is more apprent in Amazon waters than in the organiccolored surface waters found in the United States. The visible absorbance spectra of a black-water sample collected at a spring draining a poszol on the 60-Kilometer Reserve of INPA is shown in Figure 2.

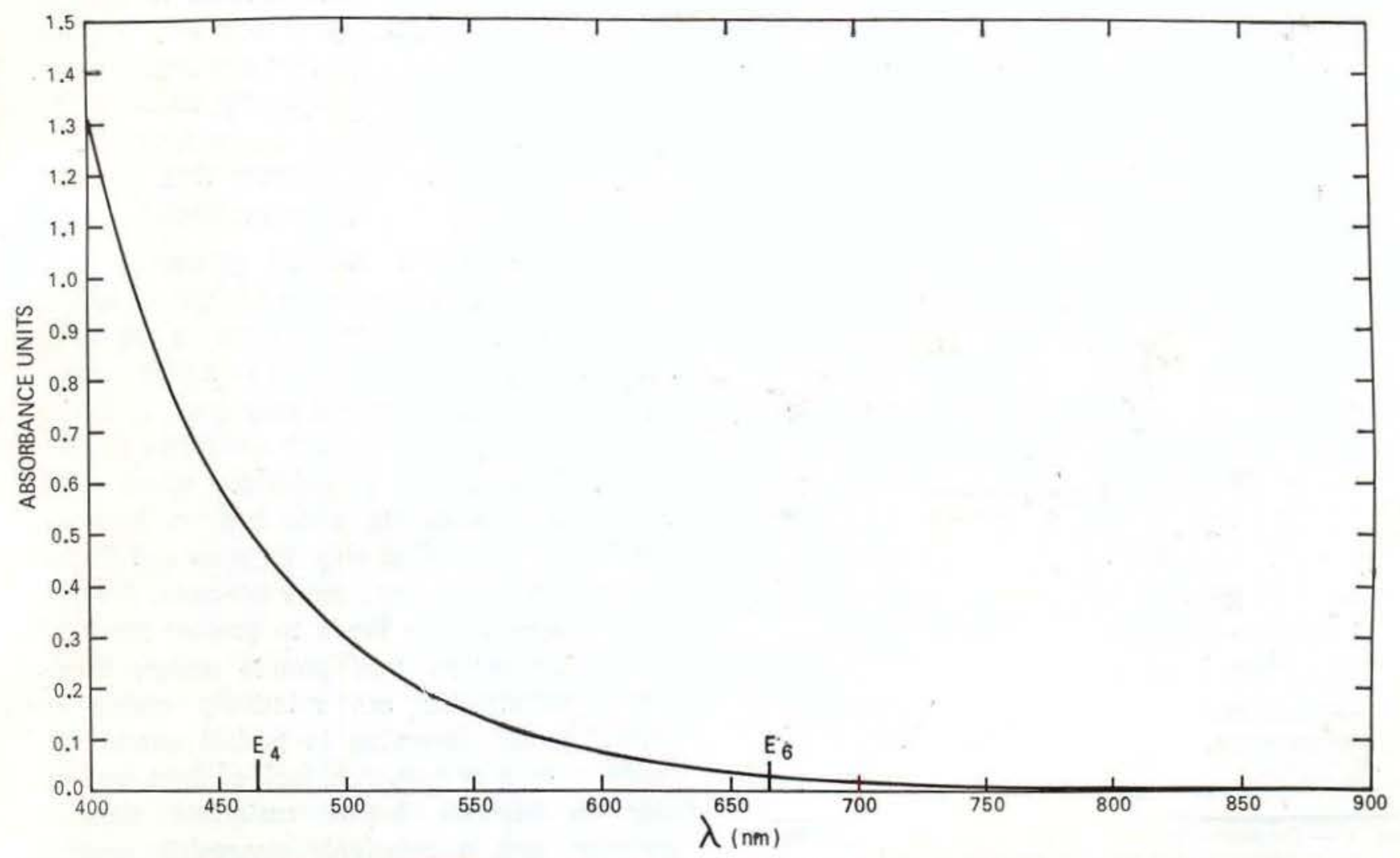

Fig. 2 - Visible absorbance spectra of black-water drainage from a podzol. 
Most light absorbance is in the blue region of the spectrum, and the water is almost transparent to red light, which explains the red coloration of the water. The ratio of absorbances of dilute aqueous solutions of humic materials at 465 and $665 \mathrm{~nm}$ (called the $E_{4} / E_{6}$ ratio) has commonly been used to characterize humic materials. A listing of $E_{4} / E_{6}$ ratios for soil and water humic extracts from the Amazon and from North America is given in Table 1.

\section{TABLE $1-E_{4} / E_{6}$ ratios of humic substances from soils and waters of the Amazon region and North America}

Sample

$\mathrm{E}_{4} / \mathrm{E}_{6}$ Ratio

1. Water Samples

a. Black water from spring draining a podzol at INPA 60 Kilometer Reserve

b. Suwannee River sampled near Fargo, Georgia *

2. Soil Extracts

a. Extract (hydrogen-saturated) from spodic horizon of podzol where sample la was collected

b. $E_{4} / E_{6}$ range for soil humic acids $\dagger$

3.8- 5.8

c. $E_{4} / E_{6}$ range for soil fulvic acids $\dagger$

\footnotetext{
(*) - Personnel communication from E. M. Thurman and R. L. Malcolm.

(t) - From Schnitzer \& Kahn, 1978.
}

Data in Table 1 indicate that black water has an exceptionally high $E_{4} / E_{6}$ ratio compared to other water and soil extracts. A recent report by Chen et al. (1977) found that the $E_{4} / E_{6}$ was inversely related to particle size, and directly related to free-radical content. Therefore, the high $E_{4} / E_{6}$ ratio for black water suggest that these humic solutes have relatively small particle sizes and high free radical contents.

\section{ACIDITY OF HUMIC SOLUTES IN BLACK WATER}

Duplicate titrations of the black-water sample collected from the spring draining of a podzol at the INPA 60-Kilometer Reserve yielded $0.45 \mathrm{meq} / \mathrm{L}$ total acidity when titrated

from $\mathrm{pH} 3.75$ to $\mathrm{pH} 8.5$. Titrations of the humic-solute fraction isolated on XAD-8 resin gave a value of $0.24 \mathrm{meq} / \mathrm{L}$; therefore, humic solutes contributed 53 percent of total acidity. The remaining acidity in the black-water sample originated from dissolved carbonic acid and low molecular-weight colorless organic acids. Dissolved organic carbon fractionation analysis of this sample indicated that 52 percent of dissolved organic carbon was related to humictype acids, and 33 percent was related to colorless organic acids. Assuming acid equivalent weights of these two acid fractions are the same, about 85 percent of the acidity is related to organic acids, and only 15 percent is due to dissolved carbonic acid. This estimate is reasonable, because when this same sample was purged of dissolved $\mathrm{CO}_{2}$ by five minutes of vigorous stirring, the $\mathrm{pH}$ rose from 3.75 to 4.0 , which corresponded to $.05 \mathrm{meq}$ or 11 percent of total acidity determined by titration.

Although these data are valid for only one black-water sample, dissolved organic carbon fractionation analyses presented later in this report indicate that this particular black-water sample has a similar organic-solute distribution as numerous biack-water rivers in the Rio $\mathrm{Ne}$ gro region. Therefore, most acidity in black waters can be attributed to dissolved-organic solutes, and not to dissolved-carbonic acid.

Dissolved Organic Carbon Fractionation Analysis of Amazon Waters.

The organic compound classes of the organic-solute mixture which is found in various surface waters of the Amazon region was determined by dissolved organic carbon fractionation (DOC) analysis. DOC fractionation data for "black waters" are presented in Table 2; the means, standard deviations, and coefficients of variation are presented in Table 3. DOC fractionation data for sediment-containing "white waters", and a sediment-free "clear water" sample from the Amazon region are presented in Table 4; Table 5 presents DOC fractionation data for "black water" and "white water" sampled in North America.

Black waters are characterized by high percentages of organic acids. The highest organic-carbon percentage (52 percent of DOC) is found in the hydrophobic-acid fraction which 
contains humic and fulvic acids. Hydrophilic acids, which are primarily low molecularweight hydroxy and fatty acids, are also quite abundant ( 35 percent of DOC). The remaining four compound classes account for only 13 percent of DOC. This fractionation pattern indicates a high degree of oxidative decom. position for organic solutes found in black waters.

TABLE 2 - Dissolved organic carbon fractionations of "black waters" from the Rio Negro basin, in percentage of $\mathrm{DOC}$

\begin{tabular}{llll}
\hline Acid & Neutral & Base Total \\
\hline
\end{tabular}

Black water from spring draining podzol at INPA 60-Kilometer Reserve

\begin{tabular}{lcccc} 
& \multicolumn{2}{c}{$\mathrm{DOC}=34.6$} & $\mathrm{pH}=3.75$ & $\mathrm{Sp}$. Cond. $=30 \mu \mathrm{S}$ \\
\cline { 2 - 5 } Hydrophobic & 52 & 0 & 0 & 52 \\
Hydrophilic & 33 & 14 & 1 & 48
\end{tabular}

Rio Negro at Narrows above Manaus $\underline{\mathrm{DOC}}=10.0 \mathrm{pH}=5.2 \quad$ Sp. Cond. $=11 \mu \mathrm{S}$

\begin{tabular}{lllll}
\cline { 2 - 5 } Hydrophobic & 53 & 8 & 1 & 62 \\
Hydrophilic & 33 & 3 & 2 & 38
\end{tabular}

Rio Negro above Rio Branco

\begin{tabular}{cccc}
$\mathrm{DOC}=11.7$ & $\mathrm{pH}=4.2$ & Sp. Cond. $=12 \mu \mathrm{S}$ \\
\hline 56 & 5 & 0 & 61
\end{tabular}

$\begin{array}{lllll}\text { Hydrophilic } & 34 & 0 & 5 & 39\end{array}$

Rio Cuieiras at Mouth

$\mathrm{DOC}=8.2 \quad \mathrm{pH}=4.7 \quad$ Sp. Cond. $=15 \mu \mathrm{S}$

$\begin{array}{lllll}\text { Hydrophobic } & 46 & 3 & 1 & 50 \\ \text { Hydrophilic } & 41 & 6 & 3 & 50\end{array}$

Rio Apuau at Mouth

\begin{tabular}{lcccc} 
& \multicolumn{2}{c}{$\mathrm{DOC}=10.4$} & $\mathrm{pH}=4.7$ & $\mathrm{Sp}$. Cond. $=11 \mu \mathrm{S}$ \\
\cline { 2 - 5 } Hydrophobic & 54 & 6 & 1 & 61 \\
Hydrophilic & 33 & 4 & 2 & 39
\end{tabular}

Rio Camanau at Mouth

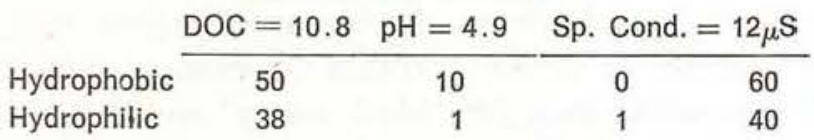

Rio Jauaperi at Mouth

\begin{tabular}{lcccc} 
& \multicolumn{2}{c}{$\mathrm{DOC}=8.4$} & $\mathrm{pH}=5.2$ & \multicolumn{2}{c}{ Sp. Cond. $=19_{\mu} \mathrm{S}$} \\
\cline { 2 - 6 } Hydrophobic & 50 & 11 & 1 & 62 \\
Hydrophilic & 34 & 2 & 2 & 38 \\
\hline
\end{tabular}

TABLE 3 - Mean, standard deviation, and coefficient of variation of fraction percentages for 7 black-water samples

(DOC mean for river samples $=9.9 \mathrm{mg} / \mathrm{L}$ )

\begin{tabular}{lccc}
\hline & Mean & $\begin{array}{c}\text { Standard } \\
\text { deviation }\end{array}$ & $\begin{array}{c}\text { Coefficient of } \\
\text { variation }\end{array}$ \\
\cline { 2 - 4 } Total hydrophobic & 59 & 5 & 0.08 \\
Total hydrophilic & 41 & 5 & .13 \\
Hydrophobic acid & 52 & 3 & .05 \\
Hydrophobic neutral & 6 & 4 & .67 \\
Hydrophobic base & .5 & .5 & 1.00 \\
Hydrophilic acid & 35 & 3 & .09 \\
Hydrophilic neutral & 4 & 5 & 1.25 \\
Hydrophilic base & 2 & 1 & .50 \\
\hline
\end{tabular}

TABLE 4 - Dissolved organic carbon fractionations of "white waters" and "clear waters" from the Amazon River basin, in percentage of DOC

\begin{tabular}{lcccc}
\hline & Acid & Neutral & Base & Total \\
\hline \multicolumn{1}{r}{ Rio Solimoes (white water) above the Rio Negro } \\
& $\mathrm{DOC}=4.1$ & $\mathrm{pH}=4.9$ & Sp. Cond. $=$ & $72 \mu \mathrm{S}$ \\
\cline { 2 - 5 } Hydrophobic & 35 & 16 & 3 & 54 \\
Hydrophilic & 40 & 4 & 2 & 46
\end{tabular}

Rio Branco (white water) sampled 20 kilometers above mouth on Rio Negro

\begin{tabular}{|c|c|c|c|c|}
\hline & $\mathrm{DOC}=2.0$ & $\mathrm{pH}=6.5$ & Sp. Cond. = & $33 \mu \mathrm{S}$ \\
\hline nhohic & 21 & 35 & 0 & 56 \\
\hline Hydrophilic & 36 & 0 & 8 & 44 \\
\hline
\end{tabular}

Barro Branco (clear water) sample at INPA Reserve Ducke

\begin{tabular}{lcccc} 
& $\mathrm{DOC}=4.7$ & $\mathrm{pH}=4.5$ & Sp. Cond. $=9.0 \mu \mathrm{S}$ \\
\cline { 2 - 6 } Hydrophobic & 39 & 20 & 2 & 61 \\
Hydrophilic & 36 & 3 & 0 & 39 \\
\hline
\end{tabular}

TABLE 5 - Dissolved organic carbon fractionation of "black water" and "white water" in North America, in percentage of DOC

\begin{tabular}{cccc}
\hline Acid & Neutral & Base & Total \\
\hline Suawannee River (black water) & sampled near & Fargo, \\
Georgia (USA) $\left(^{*}\right)$ & & \\
DOC $=30.2$ & $\mathrm{pH}=4.1$ & Sp. Cond. $=$ & $42 \mu \mathrm{S}$ \\
\hline 58 & 0 & 0 & 58 \\
36 & 1 & 5 & 42
\end{tabular}

Average of 10 "white water" samples collected in the White River Basin, Utah (USA)

\begin{tabular}{crcc}
$\mathrm{DOC}=7.3$ & $\mathrm{pH}=8.0$ & Sp. Cond. $=2,430 \mu \mathrm{S}$ \\
\hline 36 & 7 & 0.3 & 43 \\
40 & 14 & 3 & 57
\end{tabular}

(") - Data furnished by R. L. Malcolm, U, S, Geological Survey, Denver, Colorado. 
Data for seven black-water samples were very similar, with the exception of the Rio Cuieiras sample. The lower percentage of organic acids in this sample is probably related to the diluting effect of "clear waters", which drain the latosols of this region. This sample also had the lowest DOC concentration for black-water samples. Black water obtained from the spring draining the podzol contained a moderate concentration of hydrophilic-neutral solutes, which probably are soluble-soil carbohydrates. As this fraction is low in all the river samples, this fraction probably is biodegraded very rapidly in surface waters of this region.

No significant difference was observed between DOC fractionation data of black waters of the Rio Negro basin and black water of the Suwannee River in North America; however, DOC concentrations of black waters of the Rio Negro were only one-third the DOC concentration of the Suwannee River. Comparison of dissolved organic carbon data collected by Williams (1968) on Amazon surface waters with data collected by Beck et al. (1974) on black waters in the southeastern United States indicates a four-fold difference in DOC concentrations. Rio Negro black waters probably have lower DOC concentrations, because of the diluting effect of greater amounts of rainfall, and because they are diluted by low DOC clear waters. which drain the latosols occurring extensively in black-water regiens. Black-water rivers of southeastern United States receive most of their water input from swamps, where organic solutes are formed; the dilution effect is not nearly as great. When black waters were obtained near their sources, there was no significant difference in DOC content; as the black-water spring in South America yielded a DOC of $34.6 \mathrm{mg} / \mathrm{L}$, and Suwannee River water at the outlet of the Okefenokee Swamp contained a DOC of $30.2 \mathrm{mg} / \mathrm{L}$.

No evidence was found for tannic acid or other polyphenols in Amazon black-water rivers. Colored tannins and other natural polyphenols are weak acids that will adsorb on XAD-8 resin up to $\mathrm{pH} 10$, and are classified as hydrophobic acids. No color was observed to sorb on XAD-8 resin down to $\mathrm{pH} \mathrm{4}$, at which point humic and fulvic acid began to adsorb.
The clear water sample (Barro Branco) contained lower concentrations of organic acids than black water, and greater concentration of hydrophobic-neutral solutes. The Rio Branco, which was a mixture of clear water and white water at this time of year, also showed lower organic acids, a higher hydrophobic-neutral content, and the highest content of hydrophilic bases of all the samples which were fractionated. Suspended sediment of the Rio Branco was light-green in color; indicating growth of phytoplankton. The higher percentage for the hydrophobic neutral fraction in clear. water samples may be due to the presence of chlorophyl-C excretions of lysis of phytoplankton; likewise, the higher hydrophilic base fraction in clear waters may be the result of amino acids, proteins, and aliphatic amines excreted or lysed by phytoplankton.

The white-water sample (Rio Solimões) gave a DOC fractionation pattern which was almost identical to white-water samples obtained in the United States, with the exception of the hydrophilic-neutral fraction, which was much higher for North American samples. This difference is most likely related to biodegradable carbohydrate solutes, which are rapidly degraded in the warm Rio Solimões, but are more stable in the cool surface waters from Utah, sampled in the winter season.

Comparison of organic-solute fractionation patterns resulted in more similarities than differences between comparable surface waters of temperate and tropical climatic zones. Major differences in organic-solute fractionation patterns do exist between black water and white water, with clear water intermediate between these two extremes. Presence of suspended sediment in white water causes the percentage of hydrophobic solutes (especially hydrophobic acids) to decrease, due to adsorption of humic and fulvic acids upon suspended sediment.

HUMIC: FULVIC ACID RATIOS IN SOIL AND WATER

Ratios of humic acids to fulvic acids in soil and water extracts were determined for insight into the relative mobility of these natural organic acids in Amazon soils and water (only 
colored organic solutes were measured). The results are presented in Table 6 .

In the podzol soil where black water originates, about threefourths of the extractable humic solutes in the surface litter layer are humic acids In the spodic horizon of this podzol, the percentage of humic acids increases to 84 percent. Preferential leaching losses of fulvic acid from the spodic horizon results in a correspondingly high concentration of fulvic acid (65 percent of all humic-type solutes) in the resulting black-water leachate.

The surface litter layer of latosol soil contains about the same ratio of humic to fulvic acid as podzol soil; however, the percentage of fulvic acid increases with depth in the soil profile, instead of decreasing with depth, as in podzol soil. As clear water drains latosolic soils, humic solutes which originate in the surface litter layer must either be adsorbed by soil or degraded. The increasing percentage

TABLE 6 - Humic: fulvic acid ratios in extracts from Amazon soils and water

Humic acid
(percent) $\quad \begin{gathered}\text { Fulvic acid } \\ \text { (percent) }\end{gathered}$

1. Black water from spring draining podzol at INPA 60-Kilometer Reserve

2. O horizon (litter layer) of Sample 1

35

72

84

of Sample 1

4. O Horizon (litter layer) of latosol sampled at Reserve Ducke

5. A Horizon of latosol sampled at Reserve Ducke

6. B Horizon of latosol sampled at Reserve Ducke

1. Organic detritus in blackwater stream draining podzol at INPA 60-Kilometer Reserve

8. Organic detritus from Barro Branco (clearwater) at Reserve Ducke

9. Bed sediment from Rio Negro collected in the lower Anavilhanas Archipelago of fulvic acid in the A and B horizons of latosol soil indicates that fulvic acid is more mobile than humic acid, and is leached to greater depths. However, thinness of the A horizon (only $5-20 \mathrm{~cm}$ ), and the small quantity of extractable fulvic acid from the B horizon, indicate that clays in latosols are very effective adsorbents for fulvic acids as well as humic acids.

Organic detritus in black water contains more extractable fulvic acid than organic detritus found in clear water, because blackhigh water detritus is in adsorptive equilibrium with concentrations of fulvic acid found in black water.

The extract of recently-deposited beb sediment obtained from the Rio Negro contains mostly humic acids, indicating that suspended sediment selectively adsorbs humic acids from black water. In general, low concentration of suspended sediment in black-water rivers is one of the main reasons that high concentrations of both humic and fulvic acids are maintained. Without suspended sediment, there is no adsorbent surface other than the river bottom, upon which humic and fulvic acids can adsorb. .

\section{ELEMENTAL ANALYSIS OF ORGANIC MATTER} IN SOILS AND WATER

Elemental compositions (C, H, N, O) of organic constituents found in various soils and waters of the Rio Negro region are given in Table 7. All the analyses are typical for various organic-matter mixtures of humic and fulvic acids, as described by Schnitzer (1978), with the exception of nitrogen in the black-water sample from the podzol. Whole-water residue of the podzol balck water, which contains only 0.89 percent $N$, and XAD-8 resin humic-solute extract which contains even less $\mathrm{N}(0.76$ percent) exhibit exceptionally low values for organic nitrogen.

The Rio Negro's dissolved organic matter contains more nitrogen ( 1.7 percent) than is contained in organic matter isolates of the black-water rivers (1.1 percent $N$ ) of the southeastern United States (Beck et al., 1974). A clue to discrepancy in nitrogen content of 
TABLE 7 - Organic elemental analyses of soil and water extracts

(Percentage of elements are adjusted to an ash-free basis)

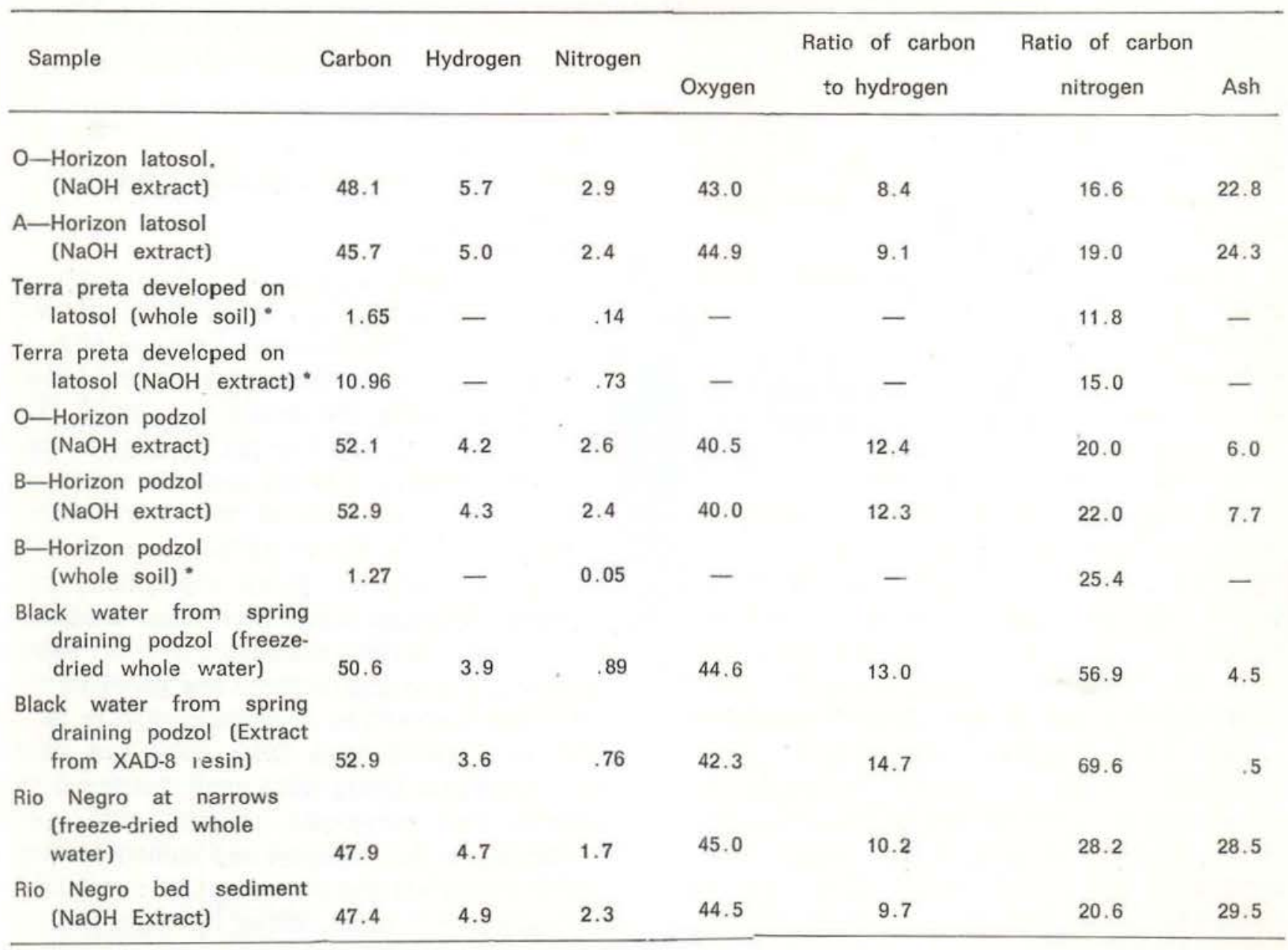

(*) - Analysis uncorrected for ash.

podzol black water versus Rio Negro black water is the lower percentage of nitrogen in the XAD-8 resin isolate of podzol black water than in the whole black-water sample. Whole water analyses include non-humic forms of nitrogen, such as amino acids, amino sugars, proteins, and inorganic forms of nitrogen; whereas analysis of the organic isolate from XAD-8 resin contains only humic forms of organic nitrogen. Higher percentages of the hydrophilic-base fraction and hydrophobicneutral fraction for Rio Negro black water versus podzol black water (Table 2) indicate that non-humic organic nitrogen content is greater in Rio Negro black water. Organic nitrogen in the humic fraction (hydrophobicacid fraction) of Rio Negro black water may be as low as the XAD-8 resin extract from podzol black water, because the extract contains only humic-type nitrogen.

Clays in soils and sediments appear to have a high affinity for organic nitrogen. Evidence for this affinity is the carbon-to-nitrogen ratio being lower for Rio Negro bed sediment than for Rio Negro water; lower for claycontaining latosols than for podzols where clay content is low: lower for water samples free of clay sediments than soil samples; and lower for latosoi soil extracts than whole soil, which indicates non-extractable nitrogen tightly bonded to the clay.

Terra Preta latosol was examined in greater detail because of its high organic-nitrogen content. Much of the organic matter in the soil 
was observed to be non-extractable, which indicates stable clay-organic matter complexes. These clay-organic complexes were hydrolyzed with $6 \mathrm{~N} \mathrm{HC1}$, and the hydroloyzate contained an extremely low C: $\mathrm{N}$ ratio of 2.3:1. As Terra Preta latosols are among the most productive agricultural soils of the Amazon region, additional investigations into the genesis of these soils and the stability of the organic matter would be warranted.

Latosols contain more extractable fulvic acid than do podzols, as shown by lower-carbon percentage and higher-oxygen percentage. Fulvic acid increases with depth in the latosol and decrease with depth in the podzol. These results agree with the humic: fulvic acid ratios presented in Table 6; however, elemental composition of XAD-8 podzol black-water extract appears more like humic acid than fulvic acid, whereas the humic: fulvic acid ratio of this sample suggests that it is two-thirds fulvic acid. The answer to this apparent paradox lies in the fact that published fulvic-acid eiemental analyses usually include non-humic organic matter, such as carbohydrates, which is oxygen-rich and carbon-poor. Humic solutes isolated on XAD-8 resin contain much less nonhumic material; therefore, the carbon percentage is greater and oxygen percentage is lower than for a "representative" fulvic acid. Latosol extracts must contain considerable nonhumic organic matter because their carbon contents are are lower and oxygen contents higher than the humic: fulvic acid ratio indicates (Table 6).

Carbon and oxygen percentages for unfractionated, dissolved-organic matter of the Rio Negro agree well with the elemental composition published for black-water rivers in the southeastern United States (Beck et al., 1974). Similarity of elemental compositions of Rio Negro organic matter to the latosol extracts suggests that much organic matter input to the Rio Negro arises from organic solutes contained in clear water which drains latosol regions. DOC fractionation data (Table 2) of certain rivers, such as the Rio Cuieiras, which is a tributary to the Rio Negro, also suggest that as much as half the organic solutes may originate from clear waters draining latosols.
Therefore. only about 50 percent of organic carbon in black water can be related to colored humic solutes (hydrophobic-acid fraction) which originate from podzols; the remaining 50 percent is not visibly apparent because it is colorless.

\section{INFRARED ANALYSIS OF SOIL AND WATER EXTRACTS}

Infrared spectra of humic substances give very useful information concerning general similarities or dissimilarities between various types of organic matter; give limited information concerning the nature and distribution of various functional groups; and give very little information about the chemical siructure of the carbon skeleton of humic materials. Absorption bands are broad because of overlapping of functional group absorptions and extensive hydrogen bonding of polar functional groups. For humic substances, the following functional group assignments are given to the following frequencies (Schnitzer, 1978): 3400 $\mathrm{cm}^{-1}$ (hydrogen-bonded $\mathrm{OH}$ ); 2929 and 2860 $\mathrm{cm}^{-1}$ (aliphatic $\mathrm{C}-\mathrm{H}$ ); $1725 \mathrm{~cm}^{-1}$ (carbonyl of ketones and carboxylic acids); $1630 \mathrm{~cm}^{-1}$ (hydrogen-bonded carbonyl and quinone); 1400 $\mathrm{cm}^{-1}$ (carboxylate and aliphatic C-H); and 1200 $\mathrm{cm}^{-1}$ (carboxylic acid). Water hydrogen-bonded to humic substances intensifies absorption bands at $3400 \mathrm{~cm}^{-1}$ and $1630 \mathrm{~cm}^{-1}$. Kaolinite clay gives several well-defined adsorption bands at $3700 \mathrm{~cm}^{-1}, 3655 \mathrm{~cm}^{-1}, 3625 \mathrm{~cm}^{-1}, 1115$ $\mathrm{cm}^{-1}, 1095 \mathrm{~cm}^{-1}, 1035 \mathrm{~cm}^{-1}, 1010 \mathrm{~cm}^{-1}, 915$ $\mathrm{cm}^{-1}, 540 \mathrm{~cm}^{-1}$, and $470 \mathrm{~cm}^{-1}$. Non-crystalline silicates give broader absorption bands at 1080 $\mathrm{cm}^{-1}$ and $800 \mathrm{~cm}^{-1}$.

Infrared spectra of organic matter in black water and Rio Negro bed sediment are pre sented in Figure 3 . The two spectra for black water draining the podzol are very similar to spectra of soil fulvic acid (Schnitzer, 1978). Strong absorption bands for hydroxyl, carbonyl, free carboxyi, and carboxylate functional groups illustrate the acidic character of this fulvic acid. There are no significant absorption bands indicating silicates. Both the whole-water sample and the extract from XAD-8 resin give identical spectra, which illustrates the lack of 


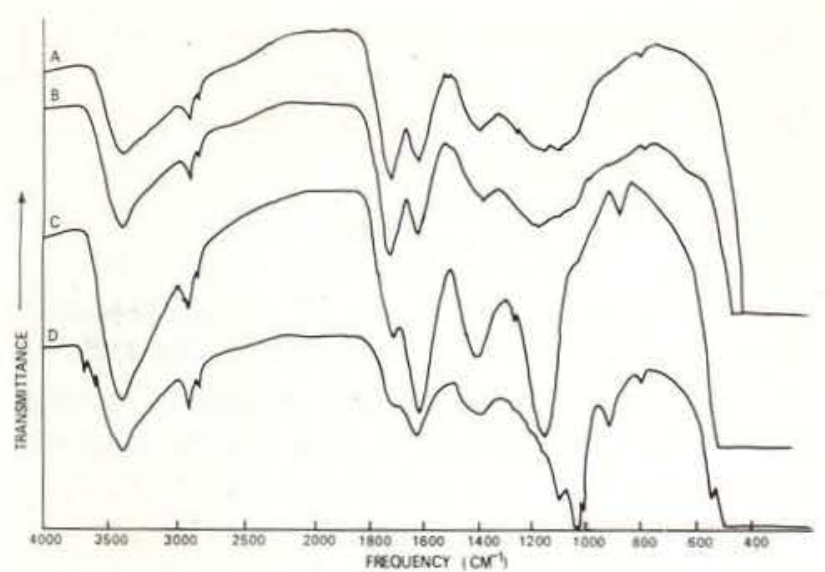

Fig. 3 - Infrared spectra of organic matter in black water and bed sediment. $A=$ Freeze-drided whole black water from podzol. $B=$ Hydrophobic acid extract from XAD-8 resin of podzol black water. $C=$ Freezedried whole Rio Negro water. $\mathrm{D}=\mathrm{NaOH}$ extract of Rio Negro bed sediment.

inorganic solutes in this water; the use of XAD-8 resin, dilute $\mathrm{NaOH}$, and cation-exchange resin did not perceptibly alter the humic material as characterized by infrared analysis, and the non-humic organic material found in this water by DOC fractionation analysis and elementai analysis cannot be seen in the infrared spectra of the whole-water residue.

The infrared spectra of the Rio Negro wholewater residue is very similar to the Rio Negro bed-sediment extract, except for the kaolinite clay shown in the latter. Strong absorption bands for noncrystalline silicates are found in the water sample; lesser amounts are tound in the bed-sediment extract. These infrared spectra from the Rio Negro show greater similarities to the spectra of humic extracts from the latosol (Figure 4) than extracts from black water from the podzol. This is additiona! evidence that the Rio Negro contains significant dissolved organic matter derived from clear water draining latosols.

Infrared spectra of humic extracts from various horizons from latosols and podzols are presented in Figure 4. Latosol extracts contain significant amounts of kaolinite, whereas podzol extracts contain almost no kaolinite and only a small amount of non-crystalline silicates. As all the soil extracts were filtered through a $\quad 0.45-\mu \mathrm{m}$ porosity filter, kaolin-crystallite dimensions are colloidal in size, and most likely are complexed to humate solutes.

Infrared spectra of the B-horizon of the podzol represents primarily a humic-acid spectra, whereas black-water spectra from this same podzol represents a fulvic-acid spectra. Remaining infrared spectra of Figures 3 and 4 represent various mixtures of humic acid, fulvic acid, non-humic organic matter, kaolin, and non-crystalline silicates.

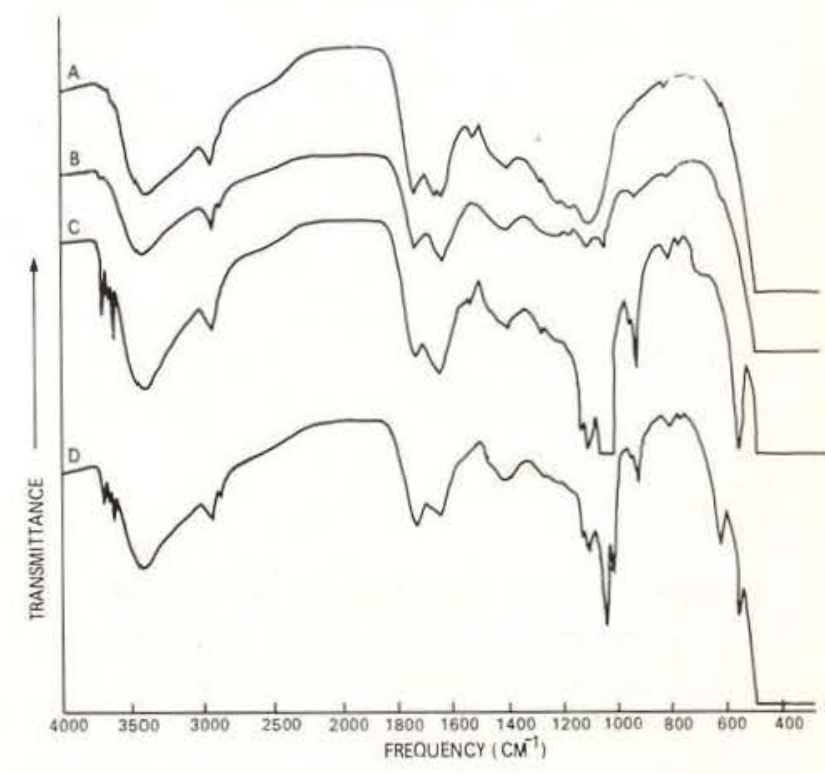

Fig. 4 - Infrared spectra of extractable organic matter in latosolic and podzolic soils. $A=0$-Horizon Podzol. $\mathrm{B}=\mathrm{B}$-Horizon Podzol. $\mathrm{C}=\mathrm{O}$-Horizon Latosol. $\mathrm{D}=\mathrm{A}$-Horizon Latosol.

\section{MOLECULAR-SIZE DETERMINATIONS OF HUMIC SOLUTES IN BLACK WATER}

Low-angle $\mathrm{X}$-ray scattering data for humic solutes from podzol black water gave radii of

$$
0 \quad 0
$$

gyration of 5.9 A-18.2 A for these solutes dissolved in distilied water, and radii of O

gyration of 11.5-16.6 A for these solutes dissolved in $\mathrm{pH}-7$ phosphate buffer. These radii of gyration are generally smaller than are found for soil-humic acids, which have radii of gyration range from about $10 \AA$ to $>100 \AA$ 
(Wershaw \& Pinckney, 1973b); however, no radii of gyration data are known to exist for soil-fulvic acias and humic solutes in river water, on which to base a comparison.

Chen \& Schnitzer (1976) determined by viscosity measurements that the shape of fulvic-acid solutes in water were more like rods than spheres; at $\mathrm{pH} \mathrm{3}$, where the minimummolecular dimension occurred, average length 0

of the rod was $53 \mathrm{~A}$, and average diameter was O

6 A. Assuming that low-angle X-ray scattering data are comparable to viscosity data, aimensions for humic solutes from podzol black water again appear to be small in relation to fulvic acid. Lastly, if the $E_{4} / E_{6}$ ratio data presented in Table 1 are inversely related to molecular size, these data also suggest that humic solutes from podzol black water are small in relation to molecular sizes normally found for humic materials in soil and water.

\section{CONCLUSIONS}

Soluble humic substances which are responsible for coloration of black waters found in the Amazon River Basin only account for about one-half of the soluble-organic matter in these rivers. Remaining organic solutes consist mostly of colorless organic acids. Elemental composition data, infrared analyses, and DOC fractionation analyses suggest that much of the non-humic organic-solute input into blackwater rivers arises from clear-water drainage from latosol soils of the region.

Humic solutes originate primarily from ground-water drainage from shallow podzol soils, which support sufficient vegetative growth so biomass input into the podzol exceeds rates of decay. Excess biomass is converted into humic-type solutes, which are removed from podzol soil by rainfall leaching. In latosol soils, vegetative decay appears to be more rapid, and humic solutes which are produced, are irreversibly adsorbed to kaolinite clay in these soils.

Black-water rivers of the Amazon contain only one-third to one-half the dissolved-organic carbon contained in black-water rivers of southeastern United States. Dilution of highDOC black-water from podzol soil with low DOC clear water from latosol soils and dilution by high amounts of rainfall are believed to be responsible for the relatively low DOC values obtained. Although DOC values are low for the the degree of coloration of Amazon black water, the high $E_{4} / E_{6}$ ratio explains the reddish coloration of the water, and suggests a relatively small humic solute of a highly aromatic nature and (or) high free-radical content. X-ray scattering data also suggest relatively small molecular dimensions for humic solutes in Amazon black water. DOC fractionation data show that organic solutes which are closely related to plant materials (carbohydrates, amino acids, chlorophyll, and polyphenols) are almost completely absent from black-water rivers of the Amazon region.

The chemical model for Amazon blackwater humic solutes, which emerges from this study, can be described as a smal! molecule relative to most humic substances; its color spectrum suggests the presence of many chromophoric groups, which may be aromatic nuclii. quinone, or free-radical groups; and the lack of other undecomposed plant residues in black water indicate that black-water humic solutes are the end products of the humification process of decay which occurs much more rapidly in tropical soils and water than in comparable soils and water of temperate regions.

\section{ACKNOWLEDGMENTS}

This study was performed through a research grant by the Organization of America States, Department for Scientific Affairs, to the Instituto Nacional de Pesquisas da Amazonia (INPA). The U.S. Geological Survey provided laboratory, time, and salary support for the study.

The cooperation and assistance of Dr. lise Walker, (INPA-OAS coordinator), and Dr. Warwick Kerr (Director of INPA) is greatly appreciated. Drs. Wolfgam Franken and Aifred Bittner of the Max Plank Institute at INPA provided instrument and laboratory facilities. Dr. Robert L. Wershaw and Dorthy J. Pinckney, 
U.S. Geological Survey, Denver, Colorado, performed the infrared analyses and low-angle X-ray scattering analyses; they also provided valuable assistance in data interpretation. Dr. Ronald L. Malcolm and E. M. Thurman provided the DOC fractionation data and $E_{4} / E_{6}$ ratio data of the Suwannee River. Lastly, I wish to thank my wife, Cora Jean, who assisted in language translation, library research, sample collection, and laboratory analyses in Brazil.

\section{RESUMo}

Substâncias húmicas dissolvidas em rios de água preta, água branca e água clara da bacia do rio Amazonas foram comparadas com substâncias húmicas em solos podzólicos (espódico) e latossólicos (oxico) da região amazônica. Solutos orgânicos do tipo húmico em água preta originados da decomposição da matéria orgânica e drenagem da água terrestre dos solos podzólicos; a água clara escorre dos latossolos porque os solutos húmicrs coloridos são absorvidos pelos minerais de argila contidos nos latossolos.

Comparações das distribuições de soluto orgânico em águas de superfície de regiões tropicais versus águas de superfície de regiōes temperadas pela análises de fraccionação de carbono orgânico dissolvido mostram que a diferença apenas significante foi um conteúdo neutral hidrofilico inferior de águas de superfície de regiões tropicais. Este achado é indicativo dos processos mais rápidos de decomposição em águas de regiôes tropicais. Rios de água preta da Amazônia continham apenas um terço a meio conteúdo de soluto orgânico contido nos rios de água preta da região sudeste dos Estados Unidos. Cerca de $50 \%$ do carbono orgânico em águas pretas da Amazônia consistiam em solutos orgânicos não-húmicos $\mathrm{e}$ incolores.

Solutos húmicos contidos na água preta da Amazônia diferiam dos solutos húmicos encontrados no rio Suwannee à sudeste dos Estados Unidos, tendo em relação $E_{4} / E_{6}$ mais elevada no expectro de absorvância visivel, o que resultou em água de uma coloração mais avermelhada. Tanto a relação $E_{4} / E_{6}$ elevada como os dados de "scattering" de raio-x de baixo-ângulo sugerem dimensōes moleculares relativamente pequenas para solutos húmicos ou água preta da Amazônia. Análises elementares orgânicas e análises de infra-vermetho de substâncias húmicas em águas e solos amazônicos foram típicos para substâncias húmicas com exceção para o baixo conteúdo de nitrogênio para solutos húmicos em água preta.

\section{LITERATURE}

BECK, K.C.; Reuter, J.H. \& PERdue, E.M.

1974 - Organic and inorganic geochemistry of some coastal plain rivers of the southeastern United States: Geochimica et. Cosmochimica Acta, 38: 341-364.
CHEN, Y. \& SCHNITZER, M

1976 - Viscosity measurements on soil humic substances. Soil Science Society of America Journal, 40: 866-872.

Chen, Y.; Senesi, N. \& SCHNITZER, M.

1977 - Information provided on humic substances by $E_{4} / E_{\hat{o}}$ ratios. Soil Science Society of America Jornal, 41: 352-358.

Christman, R.F \& GHASSEMI, M.

1966 - Chemical nature of organic color in water. Journal of the American Water Works Association, 58: 723-741.

KLINGE, $\mathrm{H}$.

1966 - Podzol soils: a source of blackwater rivers in Amazonia. Atas do Simpósio sobre a Biota Amazonica, 3 (Limnologia): 117-126.

LEENHEER, J.A. \& HUfFMAN JR., E.W.D.

1976 - Classification of organic solutes in water by using macroreticular resins. Journal of Research of the U.S. Geological Survey, 4: 737751 .

1979 - Analytical method for dissolved-organic carbon fractionation. U.S. Geological Survey Water Resources Investigations, n. $79-4$, $16 \mathrm{p}$.

MaLColm, R.L.

1968 - Freeze-drying of organic matter, clays, and other earth materials. U.S. Geological Survey Professional Paper, 600-C, p. C211-C216.

MALColm, R.L. \& LeENHEer, J.A.

1973 - The usefulness of organic carbon parameters in water quality investigations, In: Proceedings of the 19th Annual Technical Meeting of the Institute of Environmental Sciences, Anaheim, California, p. 336-340.

Santos, Umberto de Menezes \& Santos, A. dos

1970 - Méiodo para investigações comparativas sobre materiais húmicos nas águas da regiāo amezônica. Bol. INPA. Manaus, (7): 1-4.

SCHNITZER, $M$.

1978 - Humic substances: Chemistry and reactions. In: Soil Organic Matter - M. Schnitzer and S.U. Khan, eds. New York, Elsevier, p. 1-64.

SCHNITZER, M. \& KiIAN, S.U.

1978 - Soil Organic Matter. New York, Elsevier, $319 p$.

Sioli, H.

1950 - Das Wasser in Amazonasgebiet. Forschung U. Fortschritte, Berlin, 26: 274-280.

WALLACE, A.R.

1899 - Travels on the Amazon and Rio Negro. London, Ward, Lock, and Co., Ltd. 
WERSHAW, R.L. \& PINCKNEY, D.J.

1973a- Determination of the association and dissociation of humic acid fractions by small angle X-ray scattering. Journal of Research of the U.S. Geological Survey, 1: 701-707.

$1973 \mathrm{~b}$ - The fractionation of humic acids from na. tural water systems. Journal of Research of the U.S. Geological Survey, 1. 361-366.
Williams, P.M.

1968 - Organic and inorganic constituents of the Amazon river. Nature, London, 218: 937-938.

ZIECHMANN. W.

1976 -- Huminstoffe in Sudamerikanischen fluss systemen. Amazoniana, 6 (1): 135-144.

(Aceito para publicação em 17/02/80) 